\title{
G.R.A.S.P.S Strategy: Decreasing Students' Difficulties in Writing Persuasive Text
}

\author{
Stefanie Nike Nurtjahyo, Nur Arifah Drajati, Sumardi \\ Master Degree of English Education Department Universitas Sebelas Maret, Surakarta, Indonesia
}

Email corresponding author: dave.runnie2@gmail.com

\begin{abstract}
How to cite this paper: Nurtjahyo, S. N., Drajati, N. A., \& Sumardi, S. (2019). G.R.A,S,P.S Strategy: Decreasing Students' Difficulties in Writing Persuasive Text. International Journal of Language Teaching and Education, 3(2), 158-172. https://doi.org/10.22437/ijolte.v3i2.7391
\end{abstract}

Accepted: October 06, 2019

Published: December 31, 2019

Copyright (C) 2019 International Journal of Language Teaching and Education

This work is licensed under the Creative Commons Attribution International License (CC BY 4.0). http://creativecommons.org/licenses by $/ 4.0 /$

(c) (i)

\begin{abstract}
In literacy, writing becomes an essential component. It becomes the most difficult skill to be learnt because students need to express their ideas and write them accurately. They expect interesting learning in writing process in terms of developing their writing skills. This qualitative research showed the students' ability to explore their writing skills in real-world situations by using G.R.A.S.P.S. (Goals, Rules, Audience, Situation, Product/performance, Standards). This study which was done in two cycles, was carried out in a private school in Surakarta. One class from the social program was taken for sampling. 35 students contributed to the study. Observation, questionnaire, recording, students' products, writing assessment reports were used to collect data. Findings show that students could be motivated to express their ideas. The interesting teaching-learning process in the classroom made students enjoy their roles in real-life situations. The pressure in writing became lower and the students also showed their self-confidence. These findings indicate that teachers have to use authentic assessments and performance and or product tasks to make students interactive in teaching-learning activities and use evaluation rubrics that provide students real description of their performances.
\end{abstract}

\section{Subject Areas}

Writing Skill

Keywords

Performance, Product, Strategy, Writing Skill

\section{Introduction}

Communication activities can be held in the form of spoken and written. Writing is one of the essential elements of literacy that must be learned. Hoover emphasizes that "writing is a vital component of the comprehensive synergy of literacy. It is the way to express the ideas in literary form. That is why writing should be kept a hand in, in order to participate in literate society" (Hoover 2008, p. 1).

Writing is a basic skill in language and believed to be the hardest one to teach and learn (Walters, 1987) as the writer must transcribe his/her thoughts while maintaining control over a number of aspects varying from word choice and spelling to overall text structure and layout. According to Nursisto, writing is a communication ability using the highest level of language. The most difficult level is writing. (Nursisto, 2000, p.5). 
The teaching method, the environment, the lack of student motivation, the use of the students' mother tongue, the ill-structured sentences in composition and the limited vocabulary are the main causes of the students' lack in writing. Raimes said that when students complain about how difficult it is to write in a second language, they are talking not only about the difficulty of finding the right words and using the correct grammar but also about the difficulty of finding and expressing ideas in a new language. (Raimes, 1983, p. 13).

Harmer said that writing belongs to productive skills besides speaking in which the language users require the ability to produce language both spoken and written. Through writing, the students can communicate in written form. It can be said that writing needs a process; it cannot be learned instantly (Harmer 2004, p.86). This study found that writing becomes a complex activity if the students have less ability in writing elements such as content, grammar, vocabulary, mechanic, and organization. They will get difficulties to start writing. Those difficulties and problems make the students do not feel enjoy in writing. According to Jarvis (2000), many students do not enjoy writing. They feel that because they are afraid they cannot do it correctly at the first time. Therefore, students need to practice regularly in order to have a good writing skill. Then, the students themselves or possibly the reader will understand it" (TESL Journal, vol. 8, no. 7).

Based on the Indonesian Curriculum of Senior High School (Competence Based Curriculum or 2006 Curriculum), students are hoped to develop their communicative competences both in spoken and written form, which is proven in four language skills: listening, speaking, reading, and writing. In Indonesia, writing in Senior High School is not only to fulfill one of the graduation requirements from Senior High School in the form of a practical exam but also to prepare students' study in university. Besides, the students can advance college performance and academic success, apply their writing skill in academic writing, the application letter and business proposal, reports, and memos which support them in future work. It can guide students to be a successful person and get a better position in their job. That is why writing needs to be learned at Senior High School.

This study found a strategy that makes the students feel enjoy and have low pressure in writing. G.R.A.S.P.S. strategy allows the students an opportunity to be creative. G.R.A.S.P.S. stands for Goal, Role, Audience, Structure, Product, Performance or Purpose, Standards, and Criteria. The teacher can determine the goal and standards and criteria. Meanwhile, the students choose the role, audience, structure, and product. The students can decide the issue they are most interested in social, environmental, political, local, or global- that they are would like to tackle in their writing. This study focuses on persuasive writing in this research.

Students can create their own writing by following the G.R.A.S.P.S strategy. It can make them express their idea or opinions to write easily. Besides, it also allows them to practice grammatical structures so that they can write coherent, contextual, and acceptable sentences. This study believes that by allowing the students to choose their own topics, they will feel free and motivated. According to Wiggins and McTighe (2005, p.169-170) cited by Ball (2012, p. 129), G.R.A.S.P.S. is a useful strategy to integrate writing into all content areas. When assessing content along with skill (writing) make certain that two rubrics are used; one for the content and one for the skill. An existing G.R.A.S.P.S. can be revised to fit the subject area and/or the needs of the group of students. Therefore, the G.R.A.S.P.S. strategy is excellent for differentiation. 


\section{Literature Review}

\subsection{Teaching Writing}

The success of students in learning writing is determined by the teacher's role in helping them in writing. It means that the teacher has an important role to help the students to understand and learn how to write effectively, give clear explanations and instructions and guide the students in each step of the writing process. Harmer (2004, p. 41) defined some tasks that the teachers must perform before, during, and after the process of writing. They are demonstrating, motivating and provoking, supporting, responding and evaluating. The teachers have to do demonstrate in the process of writing to make the students be able to understand writing conventions and genre constraints of particular types of writing. As a result, the teachers have to be able to draw the two features to their attention.

In the process of writing, teachers become the main supporters in supporting the students when they are doing writing in the classroom, especially when they get difficulties and feel stuck. The teachers have to help them to solve the difficulties. Thus, the students will be motivated to do their writings. Harmer stated that the teacher's roles in the teaching and learning process of writing. They will be explained as a motivator, resource, and feedback provider. When the students work on the writing tasks, the teacher must motivate them by creating a nice learning atmosphere, persuading them of the usefulness of the activity, and encouraging them to create as much as efforts to achieve the optimal result (Hammer, 2007, p. 261-262). This study inferred that teachers hold an important role in the students' success in learning writing. They have the responsibility of guiding and facilitating the students' writing by being good motivators, resource and feedback providers.

\subsubsection{Teaching Writing in Senior High School}

The curriculum designed by the central government throughout the provision of curriculum policies is used as the basis of English teaching in Indonesia. There are twelve types of text for senior high schools such as recount, narrative, procedural, descriptive report, new items, analytical exposition, persuasive exposition, spoof, explanation, discussion, and review. The syllabus is set to emphasize and make the learning process become interactive, inspirable, fun, challenging, motivating learners to involve actively, a given adequate space for innovation, creatively, autonomy based on learner's potential, interest, physical and physiological development.

\subsubsection{Persuasive Text}

Larson (2004, p. 11) said that persuasion is a process that changes attitude, beliefs, opinion, or behavior. In that definition, the process of persuasion gets attention from the receiver. It means that the purpose of persuasion is the writer or the speaker try to influence the receiver or reader to do the ideas writer or speaker without violence and coercion. He also said that the focus of persuasion is not only on the sender, the message, or the receiver, but all of them are equally focused on. All of them have to make cooperate in making a persuasive process. So, it can be said that persuasive is a result of the combined efforts of source and receiver (2004, p. 14). It can be concluded that persuasion is an effort to persuade people by using data or pieces of evidence and understand the psychological fact from a receiver.

Persuasive text, also known as the argument essay, applies factual logic and reason. It tries to persuade a reader to adopt a certain point of view or to take a particular action. The argument must always use sound reasoning and solid evidence by stating facts, giving logical reasons, using examples, and 
quoting experts. According to Junior Skill Builders (2008), it is said that argumentative (persuasive) writing is to convince the reader of your point of view on some subject; alternatively, you may be required to convince the reader to take some particular action as agreed of your opinion. To produce qualified persuasive texts, the students need to be stimulated in expressing ideas and to be guided in their writing process. Besides, they also need to be supported by providing them qualified and understandable inputs. Feez (2002, p. 4) states that creating texts requires making choices about the words that are used and how it can be put together. She also states that there are various kinds of texts called text type.

\subsection{Review of G.R.A.S.P.S Strategy}

According to Wiggins (2004), the acronym of G.R.A.S.P.S is Goal, Role, Audience, Situation, Performance/Product/Purpose, Standards, and criteria. The goal provides a statement of the task. Besides, it establishes the goal, problem, challenge, or obstacle in the task. The role defines the role of the students in the task. It states the job of the students for the task. The audience identifies the target audience within the context of the scenario. The situation sets the context of the scenario and explains the situation. Performance or Product or Purpose clarifies what the students will create and why they will create it. Standards and criteria (Indicators) provide students with a clear picture of success. It identifies specific standards of success. The teacher can issue rubrics to the students or develop them with the students The teacher can decide on the goal and the standards and criteria, and the students choose the role, audience, structure, and product. The students can decide the issue they are most interested in social, environmental, political, local, or global- that they are would like to tackle in their writing.

Wiggins (2004) added that students can explore their idea or opinions in writing. This strategy allows students to demonstrate understanding with some options in the performances and or products. It also allows students in practicing grammatical structures so that they can write coherent, contextual, and acceptable sentences. Hudelson (1989) in Thomsan (2003, p. 25) found out that the quality of writing was better when students were allowed to make decisions about their topics. This study believes that by allowing the students to choose their own topics, their work is more successful.

G.R.A.S.P.S allows students to demonstrate understanding with some options in the performances and or products. The scoring rubrics include distinct traits of understanding and successful performance. The scoring rubrics highlight what is appropriate, given the evidence needs to be suggested by the desired results. The culminating activities that the students produce are the products that are based on the goal of a performance task. Performance task-G.R.A.S.P.S is a design tool to develop a performance task with an emphasis on context and role-playing (Wiggins, G. \& Mctighe, J., 2008).

Wiggins, G. \& Mctighe, J. (2008) said that a teacher can construct in a scenario for a performance task, edit a task, remove or add products, or up-load other pertinent information to the task. Rubrics are designed for each task for each type of product. The G.R.A.S.P.S. frame includes real-world goals, meaningful roles of students, authentic or simulated real-world audiences, and a contextualized situation that involves real-world applications. In line with this, Ball (2008) mentioned that G.R.A.S.P.S. should be used as a tool when designing a classroom performance task scenario. The teacher creates performance tasks for the students as an opportunity for them to demonstrate what they know and are able to do in relation to a given concept or skill. 
Nuha Iter (2017, p. 552-558) recommends to G.R.A.S.P.S strategy should be utilized to evaluate performance tasks in all courses. Students' recommendations must be considered in reforming the course content and their results can be used as data to reform policies and practices related to the qualification program. Teachers use authentic assessments and performance tasks to make students interact in the courses. By using rubrics in evaluation provide real descriptions to students about their performances. Through the performance task, the students can value their work processes and products.

\subsubsection{Using G.R.A.S.P.S Strategy in Teaching Writing}

In this modern era, teachers can use many strategies to teach English. A new paradigm of assessment in higher education, such as performance task-G.R.A.S.P.S, is used in this study to address the main problem of this research. G.R.A.S.P.S should be used in designing a classroom performance task scenario. Tomlinson and McTighe (2006, p. 5) stated that teachers allow students to construct or perform an original response rather than just recognizing a potentially right answer out of a list provided, performance assessments can measure students' cognitive thinking and reasoning skills and their ability to apply knowledge to solve realistic, meaningful problems. Teachers create performance tasks for the students as an opportunity for them to demonstrate what they know and are able to do in relation to a given concept or skill.

The GRASPS frame includes real-world goals, meaningful roles of students, authentic or simulated real-world audiences, and a contextualized situation that involves real-world applications. Students generated culminating products and performance, and consensus-driven performance standards (criteria) are used to determine success. Performance tasks with these features provide meaningful learning targets for learners, worthy performance goals for teaching, and the kind of evidence needed to assess true understanding (Tomlinson, \& McTighe, 2006)

The teacher can construct performance tasks based on the G.R.A.S.P.S. acronym (Wiggins, et.al:2004). The teacher can provide a statement of the task and establish the goal, problem or challenge. The goal provides the student with the outcome of the learning experience and the contextual purpose of the experience and product creation. The teacher can define the role of the students in the task and provide the student with the position or individual persona that they will become to accomplish the goal of the performance task. The majority of roles found within the tasks provide opportunities for students to complete real-world applications of content. The teacher can identify the target audience and the context of the scenario. The audience is the group that is interested in the findings and products that have been created. These people will make a decision based upon the products and presentations created by the individual(s) assuming the role within the performance task. The teacher can set the context of the scenario and explain the situation Students will learn about the real-world application for the writing performance task.

The teacher can clarify what the students will need to create and why it needs to be created, provide a clear picture of what success looks like and establish the rubric for product and or performance. This is designed using multiple intelligences. The product or performance provides various opportunities for students to demonstrate understanding, depending on their learning style and abilities. Based upon each individual learner and or individual class, the educator can make appropriate instructional decisions for product/performance development. For the standards and criteria for success, the teacher can adapt this project for individual students and ensure support for learning needs (differentiation). 


\section{Research Method}

The research method used in this study is Classroom based on Action Research (CAR). The study used the four phases which is a kind of 'classic,' and it often appeared in the literature on Action Research. It was developed by Kemmis \& Taggart (2007) cited by Burns (2010, p. 9) which involved planning, acting, observing and reflecting. This study proposed a solution-G.R.A.S.P.S. strategy to develop the writing competence of second-grade students. There were four phases used in this study which is a kind of 'classic,' and it often appeared in the literature on Action Research. Kemmis and Taggart developed it (1988) cited by Burns (2010, p. 9) which involved planning, acting, observing and reflecting. These phases can be seen in figure I.

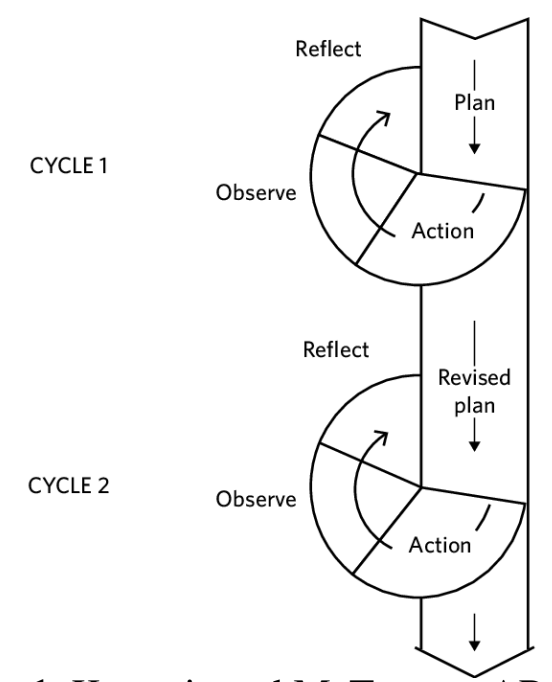

Figure 1. Kemmis and McTaggart AR model

\subsection{The Overview of the Implementation of the Research}

Table 1. an overview of the current research

\begin{tabular}{ll}
\hline Problem & Students' ability in writing is low \\
\hline Solution & Teaching Writing using G.R.A.S.P.S Strategy \\
\hline Students & The Eleventh Grade \\
\hline No. of cycle & Two cycles \\
$\begin{array}{l}\text { Cycle 1: Hortatory Exposition. Theme : Free } \\
\text { Planning }\end{array}$ & $\begin{array}{l}\text { Doing the teaching activities into three phrases: openings, main activities, } \\
\text { and closing. } \\
\text { composing hortatory exposition with the theme: Free, using } \\
\text { G.R.A.S.P.S Strategy. } \\
\text { M2: composing hortatory exposition with the theme: same with M1, using } \\
\text { G.R.A.S.P.S Strategy. } \\
\text { M3: composing hortatory exposition with the theme: same with M1, using } \\
\text { G.R.A.S.P.S Strategy. } \\
\text { Ss (Post-test Cycle 1) composing hortatory exposition with the } \\
\text { Theme: same with M1 } \\
\text { There are 34 students in the classroom. One student died be- } \\
\text { cause of a car accident. } \\
\text { Ebsements of writing have fulfilled the } K K M \text {. The } K K M \text { of writ- }\end{array}$
\end{tabular}


ing is 76. The average score increased from 79.49 in pretest into 80.94 in the post-test 1

T Prepared the material well, explained what G.R.A.S.P.S was and it was implemented in teaching writing, gave modeling, some students

CS The students can decide the thesis they are most interested in their writing make them feel easier to organize and decide the content. Group work helped the low students, activity increased and enjoyable.

Reflection

Strengths: more attentive, the teacher-centered decreased

. CS Situation

Weaknesses: The teacher explained the elements in the G.R.A.S.P.S (teaching-learning process)

. SS Ability strategy too fast and some students were absent.

(writing result)

Strengths: The elements of writing have fulfilled the $K K M$. The $K K M$ of writing is 76 . The students gained $16.44(82.2)$ in content, $16.15(80.75)$ in vocabulary, $16.03(80.3)$ in grammar, 15.97 (79.85) in mechanics and $16.35(81.75)$ in an organization.

Post Test

Weaknesses: The word amount was 400 until 450 (less than 500)

The post-test was conducted.

\section{Cycle 2: Hortatory Exposition. The theme is different. Free}

Planning

Action

Observation

Reflection

a. CS Situation

(teaching-learning

process)

b. SS Ability

(writing result)

Final Reflection
Doing the main teaching activities into three phases: opening the class, main activities and closing

M1: composing hortatory exposition with the theme: Free using

G.R.A.S.P.S Strategy.

M2: composing hortatory exposition with the theme: same with M1 using G.R.A.S.P.S Strategy.

M3: composing hortatory exposition with the theme: same with M1 using G.R.A.S.P.S Strategy.

M4: (Post Test Cycle 2) composing hortatory exposition with the theme: same with M1 with G.R.A.S.P.S Strategy.

SS Improved in content, vocabulary, grammar, content, and mechanics (spelling/punctuation).

The average score increased from 81.00 in the post-test 1 into 83.03 in the post-test 2 (34 students)

T Prepared the material well, modeling was given written, the simple presentation ran well.

Cs $\quad$ Active group work, more fun, and they could do the tasks well. They were very interested in the goal and simple presentation that they had to make. They wanted others could read their writing.

Strengths: more attentive and group work activities ran active and well. Weaknesses: There are still a few passive students.

Strengths: The elements of writing have fulfilled the $K K M$. The $K K M$ of writing is 76. The students gained 16.97 (84.85) in content, 16.65 (83.25) in vocabulary, 16.47 (82.35) in grammar, 16.35 (81.75) in mechanics and 16.59 (82.95) in organization.

The word amount reached 500 words more.

The elements of writing increased significantly. Students could do the task actively.

The class situation became very active. The students could construct the draft of the writing. They worked enthusiastically even though the class became crowded in group discussions.

The students cannot wait to show their writing to others.

The teacher could make a simple presentation run well. 
The study used a collaborator who planned to carry out a Classroom Action Research by applying G.R.A.S.P.S Strategy to improve writing skills. In applying this method, an exposition text was used. Hopefully, after this Classroom Action Research was carried out, the students were able to develop their idea and produce a text by using appropriate language features and structures.

When constructing performance tasks, it helps to use the acronym G.R.A.S.P.S. (Wiggins, et.al:2004).

1) Goal. The teacher can provide a statement of the task and establish the goal, problem or challenge. The goal provides the student with the outcome of the learning experience and the contextual purpose of the experience and product creation.

2) Role. The teacher can define the role of the students in the task and provide the student with the position or individual persona that they will become to accomplish the goal of the performance task. The majority of roles found within the tasks provide opportunities for students to complete real-world applications of content.

3) Audience. The teacher can identify the target audience and the context of the scenario. The audience is the group that is interested in the findings and products that have been created. These people will make a decision based upon the products and presentations created by the individual(s) assuming the role within the performance task.

4) Situation. The teacher can set the context of the scenario and explain the situation Students will learn about the real-world application for the writing performance task

5) Product/Performance and Purpose. The teacher can clarify what the students will need to create and why it needs to be created, provide a clear picture of what success looks like and establish the rubric for product/performance. This is designed using multiple intelligences. The product or performance provides various opportunities for students to demonstrate understanding, depending on their learning style and abilities. Based upon each individual learner and or individual class, the educator can make appropriate instructional decisions for product/performance development.

6) Standards and Criteria for Success. The teacher can adapt this project for individual students and ensure support for learning needs (differentiation).

\subsection{Reliability and Validity}

This study used to mean as a technique to describe the description of the writing competence based on the average score of the second-grade language program students. According to Sugiyono (2007, p. 49) mean is obtained by adding all the scores of the students divided by the number of the students in the group. The formula is as follows :

$$
\begin{aligned}
& \hline \text { M= } \frac{\sum \mathrm{X}}{\mathrm{n}} \\
& \text { Note : } \\
& \mathrm{M} \quad=\text { mean (average) } \\
& \begin{array}{ll}
\sum \mathrm{X} & =\text { the total score of the whole students } \\
\mathrm{n} & =\text { the number of students }
\end{array}
\end{aligned}
$$


The qualitative data will be analyzed by using the constant comparative method as suggested by Hopkins (1993, p. 149). We described in four stages of the constant comparative method: (1) comparing incidents applicable to each category; (2) integrating categories and their properties; (3) delimiting the theory; and (4) writing the theory.

\section{Research Finding and Discussion}

\subsection{Finding}

This study and the collaborator observed the process of teaching and learning in the classroom and learning progress that the students achieved. Based on the observation of this study and collaborator and interview with the students, this study could describe what really happened during the teaching-learning process. The teaching and learning process ran good enough.

G.R.A.S.P.S strategy stimulated students in learning to write. The students always found difficulties from where and how to begin the sentences when they were asked to construct paragraphs. So, by having G.R.A.S.P.S Strategy, the students actively engaged with the text. Besides, they could have a more in-depth understanding of the organizing and language features of a text in the group. Based on the result of post-test 1 , this study concluded that the students had shown their improvement in writing in cycle 1 even though they reached less than 500 words. The highest score was 84 reached by two students in post-test1. There was an improvement for the three students who got the lowest score in the pretest. They could reach 76 in post-test 1 . The post-test 1 score of cycle 1 could be shown in Graphic 1.

Graphic 1. The Post Test Score of Cycle 1

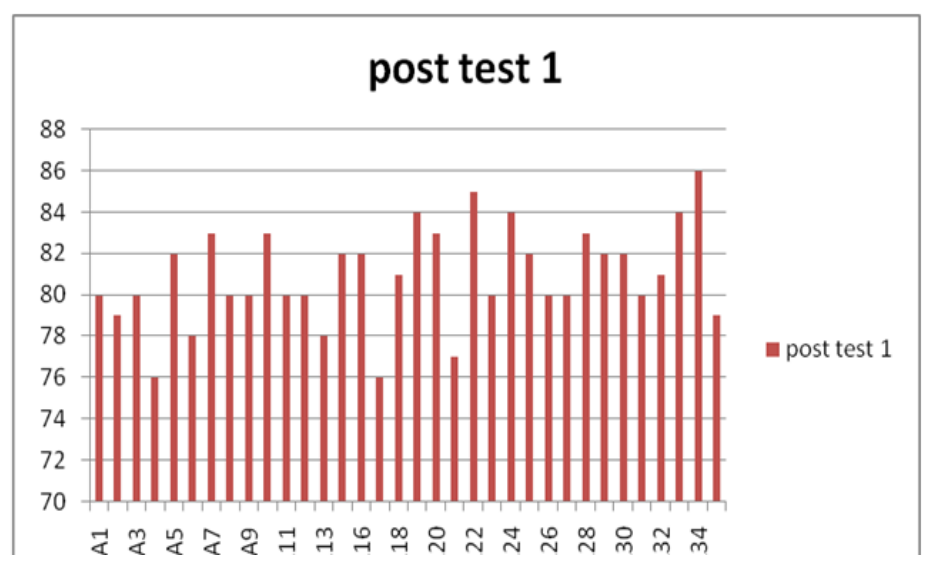

Table 2. The Students' Score of Post Test 1 Viewed from Each element

\begin{tabular}{lc}
\hline Element & Score \\
\hline Content & 82.2 \\
Vocabulary & 80.75 \\
Grammar & 80.15 \\
Mechanics & 79.85 \\
Organization & 81.75 \\
\hline
\end{tabular}

There was an improvement in Cycle 1. This study found that no one had reached 500 words in the writing. The students still focused on grammar and content. They worried if they wrote much, they would make mistake in grammar, cohesion and coherent (organization). So, this study and the collaborator 
planned Cycle 2 which emphasized improving the elements above. The observation was conducted during the cycle by this study and the collaborator. The focus of attention was the process of teaching and learning in the classroom and the progress of the students.

The teaching and learning process in the Second Cycle was better than the first. It proved that the class activities had been enjoyable for the students. Most of the students were more active in activities. They were also excited about the action after they had finished their writing; they could show their writing to others. The practice activity in Cycle 2 was more alive. Post writing activities were useful. The students learned best from their inability in Cycle 1 in writing a text or essay. They could construct sentences meaningfully and acceptable. The elements of writing had fulfilled the $K K M$. The writing score in Cycle 2 improved and fulfilled the $K K M$. It happened because the teacher used different actions in Cycle 2. The students showed improvement in writing.

Students could improve their writing skills netter by using the G.R.A.S.P.S strategy. This strategy stimulated the students in learning to write. Besides, working with friends in the group made the students feel comfortable and they could help each other. The students' writing skills in post test 2 increased with that in post-test 1. After examining the result of the students' writing in the post-test, this study concluded that there was an improvement in students' writing skills. The highest score gained by the students who got 86 in post-test 2 . The lowest score gained by a student who got 79 . The average score between post text 1 and post-test 2 improved from 80.94 to 83.06. In brief, the post-test score of Cycle 1 could be shown in Graphic 2.

Graphic 2. the Students' Score of Post Test 2

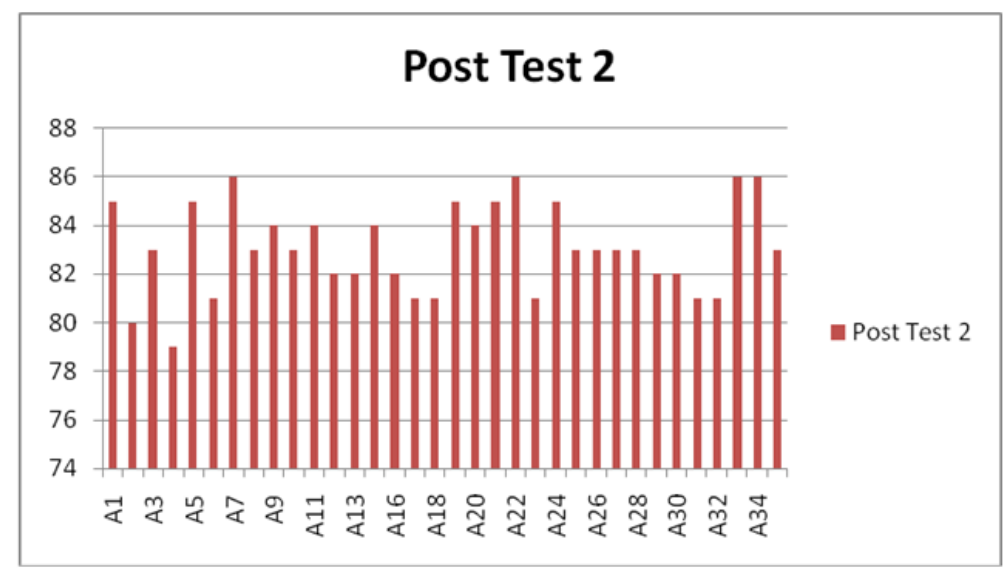

Table 3. The Comparison between the Score of Post Test 1 and Post Test 2

\begin{tabular}{clcc}
\hline \multirow{2}{*}{ No } & \multirow{2}{*}{ Explanation } & \multicolumn{2}{c}{ Students' score } \\
\cline { 3 - 4 } & & Post-test I & Post-test 2 \\
\hline 1 & The highest score & 86 & 86 \\
2 & The lowest score & 76 & 79 \\
3 & Average score & 80.94 & 83.06 \\
\hline
\end{tabular}

It was clear that the students' writing ability improved in Cycle 2. Table 4.3 showed the students' scores viewed from each element of writing. 
Table 4. Students' Score of Post Test of Cycle 2 viewed from each Element

\begin{tabular}{lc}
\hline Element & Score \\
\hline Content & 84.85 \\
Vocabulary & 83.25 \\
Grammar & 82.5 \\
Mechanics & 81.75 \\
Organization & 82.95 \\
\hline
\end{tabular}

Graphic 3. The Comparison between Post Test 1 and the Post Test 2 Scores

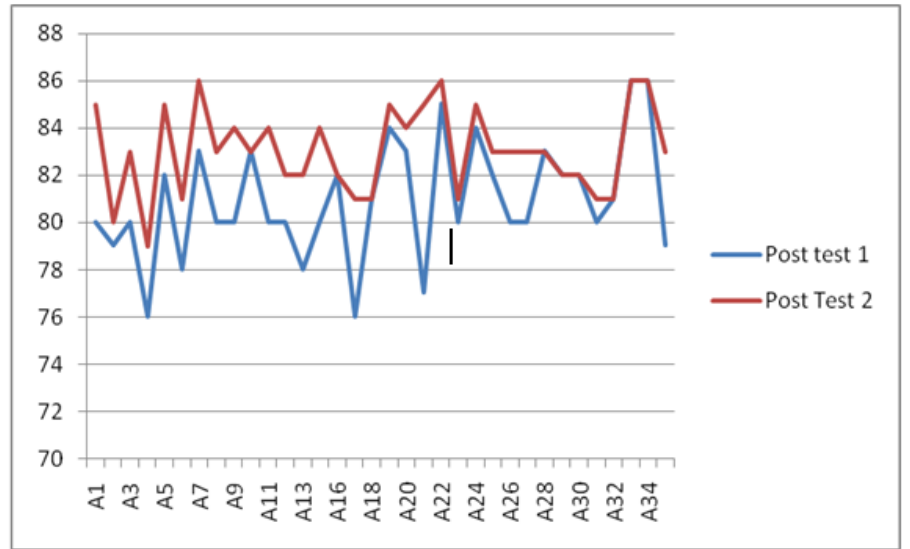

Table 5. Students' Scores of Post Test of Cycle 1 and Post Test of Cycle 2 Viewed from each Element of Writing

\begin{tabular}{ccc}
\hline \multirow{2}{*}{ Element } & \multicolumn{2}{c}{ Students' score } \\
\cline { 2 - 3 } & Post-test I & Post-test 2 \\
\hline Content & 82.2 & 84.85 \\
Vocabulary & 80.75 & 83.25 \\
Grammar & 80.15 & 82.5 \\
Mechanics & 79.85 & 81.75 \\
Organization & 81.75 & 82.95 \\
\hline
\end{tabular}

It could be seen that there was an improvement in every element of writing. G.R.A.S.P.S Strategy encouraged the students in writing class. The students could deliver their idea easier when they wanted to write a text or an essay. They could construct sentences grammatically even though they used simple sentences. The vocabulary mastery also improved because the topics of writing that they faced every meeting were different. All elements in writing also improved and fulfilled the $K K M$. The students were more active and enjoyable in doing the writing process. It happened because they worked in a group when they learned writing.

Based on observation and post-test cycles, it shows there is an improvement in students' writing skills. The improvement can be shown from the result of the comparison between the condition of the preliminary research and after the implementation of the research. The students can write a good text or an essay. Therefore, the students' scores had fulfilled the $K K M$. 
The class situation also improved. It could be seen when the students involved actively in the group. G.R.A.S.P.S Strategy gave a chance for the students to enhance their understanding of the text. It also decreased the students' passiveness and the teacher's dominance in the class.

\subsection{Discussion}

The description above has provided an overview of the research of finding the implementation of G.R.A.S.P.S strategy in teaching persuasive writing. The result of this research was satisfying in term:

4.2.1. The improvement of Students' Writing Skill;

Based on the findings, it can be theorized that the use of the G.R.A.S.P.S strategy can improve students' writing skills.

Table 4.5 Students' Scores of Pretest, Post-test of Cycle 1 and Post-Test of Cycle 2 Viewed from each Element of Writing

\begin{tabular}{cccc}
\hline Element & \multicolumn{3}{c}{ Score } \\
\hline & Pretest & Post-test I & Post-test II \\
\hline Content & 78.85 & 82.2 & 84.85 \\
Vocabulary & 79.45 & 80.75 & 83.25 \\
Grammar & 79.3 & 80.15 & 82.5 \\
Mechanics & 79.45 & 79.85 & 81.75 \\
Organization & 80.45 & 81.75 & 82.95 \\
\hline
\end{tabular}

1) G.R.A.S.P.S Strategy improved the students' writing content as it can help students to explore the idea for writing.

2) G.R.A.S.P.S Strategy helped the students when they organized their writing.

3) G.R.A.S.P.S Strategy improved the students in grammar.

4) G.R.A.S.P.S Strategy improved the students' vocabulary

5) G.R.A.S.P.S Strategy improved the students' mechanics of writing (spelling and punctuation)

In the G.R.A.S.P.S strategy, students can explore their own ideas to find out their topic in writing. The quality of writing was better when students were allowed to make decisions about their topics. Buchanan, K.P. (2001), stresses the importance of children choosing their own topics for writing. Turbill (1983, p. 43) cited by Buchanan, K.P. (2001) stated suggested that children write best, and develop most rapidly as writers when the write on topics they care about. The motivation for writing should come from the child and not from a topic a teacher has selected. Manning (1999, p.130-132) cited by Buchanan, K.P. (2001) added that when students are provided a topic, they may have insufficient background knowledge or limited interest to write effectively about it.

G.R.A.S.P.S strategy helped the students to develop their idea into well-organized text. This study asked the students in groups to discuss one topic related to health and beauty, education, lifestyle, sport, art, online games, entertainment or culture. They might also have their ideas if they had. After that, they started to find the thesis they are interested in and the arguments support it in sentences. During the discussion, the students were more active because the ideas or topics were general and interesting. Besides, they worked in groups which have the same interest. Srinivas, H. (2011) said that working in a group or collaborative learning is an educational approach to teaching and learning that involves groups of students 
working together to solve a problem, complete a task, or create a product. It is lined with the G.R.A.S.P.S strategy which asked the students to determine the product/performance/purpose besides the role, audience and situation.

The students had the opportunity to converse with peers, present and defend ideas, exchange diverse beliefs, question other conceptual frameworks, and were actively engaged. The shared learning allows students to engage in discussion, take responsibility for their own learning, and thus become critical thinkers. It can be said that it can promote critical thinking (Gokhale, A.A., 1995). It can make the students were able to organize their idea well based on the draft that they had well-managed in the generic structure.

The students could have dictionaries and hand out books to help them in enriching their vocabulary. Dictionary became an important thing in this case. The teacher moved from group to group in order to control the students' activities. Some students raised their hands if they wanted to ask some English words. So, the teacher came to the group to help them. The choice of words in their writing became more varied as they were trained to think creatively to choose the appropriate words based on the context of the situation. The choosing of their own idea for writing make them feels more curious in learning vocabulary. They were not easily got bored in the writing process. Besides, a supportive classroom atmosphere can run optimally. According to Ajabshir, Z. \& Vahdany (2017), peers can be experts and novices at the same time: more proficient and less knowledgeable learners both may contribute knowledge to each other in order to increase the level of their performance. A study of Watanabe (2008) cited by Naghdipour (2017), showed that the study showed that the three participants preferred working with group members who contributed their ideas, regardless of their proficiency level.

\subsubsection{The improvement of the teaching-learning process.}

1) The students' interest in 'writing' increased

2) G.R.A.S.P.S helps students to participate actively in writing class.

3) G.R.A.S.P.S is helpful for the students for workgroup and independent activities.

This study gave the students assistance and motivation in giving an explanation about grammar appropriate with hortatory exposition. Teaching and learning media such as computer presentation media and grammar tasks as practical skill were used in order to make the students comprehend the concept of grammar and word order (the generic structure of hortatory exposition) easier. Teachers should manage learning strategies suitable for students at a particular level in order to enhance language learning. The continuous grammar practices individual and groups can improve the students' grammar mastery. The sentences became more accurate. According to Thornbury (1999) cited by Uibu, et.al. (2015), the choice of the appropriate strategy has also been found to ensure success in further language learning as it helps to learn a language more effectively.

The students in the structure or modeling stage were given detailed explanations about how to write sentences using spelling, capitalization, and punctuation that used in hortatory exposition. In groups, the students are guided to check the mechanics of the writing. So, they could check the mechanics of their writing and their friends' writing independently. The feedbacks of the teachers and students can improve this skill. According to Mollestam \& Hu (2016, p.22), giving positive feedback is also needed to motivate the students in writing. This statement has the same line as Erkkila (2013:16). She said that teachers will 
give positive comments to arouse and strengthen the students' positive feelings to make a better paragraph.

G.R.A.S.P.S strategy can improve the students' participation in writing. The students showed were motivated more active during group activities. They could create their own writing ideas so that they can express their idea or opinions in writing easier. This study found that by allowing the students to choose their own ideas or topics, they will feel free and motivated. This strategy had put the students into a more active situation. Group work activities provided the students with more chances to have interacted with their friends. They could get a new atmosphere in the class because they could change ideas actively. The students could help each other. Research findings suggest that group work technique helps students learn better and improves their achievement (Meteetham et al., 2001).

The students can choose products and or performances. It clarifies what the students will create and why they will create it. They decide the issue they are most interested in the real-world issue, such as social, environmental, political, local, or global that they are would like to write in their writing. According to Wiggins (2004), this strategy allows students to demonstrate understanding with some options in the performances and or products.

G.R.AS.P.S strategy encourages the students to be active during the class. In the discussion session, they actively share their knowledge. Besides, they help each other their ideas to decide the issue, what they want to make- the product or performance and the audience. G.R.A.S.P.S strategy makes the students understand the material of the lesson by asking the member of the group without being afraid. They wrote by using their own words and ideas. They showed more attention during the writing process. The class was more alive. Good atmosphere was created in the class because the students can exchange their ideas actively. Finally, students could improve their writing skills.

\section{Conclusions}

This research showed that the G.R.A.S.P.S strategy can improve writing skill. Therefore, the G.R.A.S.P.S strategy is an appropriate way that can be used by teachers in teaching writing. It can overcome the problem arising in writing class. Based on the illustration above, it implies that using G.R.A.S.P.S Strategy in writing class is strongly suggested. It can help the students to develop their writing draft and construct the text or essay. The teaching steps to do G.R.A.S.P.S Strategy in the classroom are: (1) asking about interesting topic nowadays like the real-world issue and making a statement of it, (2) asking about what they want to make at the end of the writing process, such as performance and or product and the audience. The students must decide the activities by themselves, (3) giving text modeling, (4) working in a group mostly, (5) giving motivation and positive feedback to the students. G.R.A.S.P.S strategy can motivate the students in expressing their ideas; The interesting teaching-learning process in the classroom will make the students feel enjoyed because of their roles in real-life situations. It can low pressure in writing; The students also showed their self-confidence.

\section{References}

[1] Ball, Patrice (2012). GRASPS: A focus on writing. Aligned to the Wisconsin State Standards and MPS Learning Targets. 
[2] Carr, W., \& Kemmis, S. (2005). Becoming critical: Education, Knowledge and Action research. London: Falmer Press.

[3] Creswell, J. W. (2008). Educational research: Planning, conducting, and evaluating quantitative and qualitative research (3rd ed.). Upper Saddle River: NJ: Pearson.

[4] DeWalt, Kathleen M. \& DeWalt, Billie R. (2002). Participant observation: a guide for fieldworkers. Walnut Creek, CA: AltaMira Press.

[5] Erkkila, M., (2013). Teacher Written Feedback: Teachers' Perception of Given Feedback. Department of Languages English, University of Jyvaskyla. P. 16.

[6] Fakher Ajabshir, Z. \& Vahdany, F. (2017). The Effect of Peer Scaffolding on Developing L2 Pragmatic Knowledge: A Sociocultural Perspective. International Journal of English Language \& Translation Studies. 5(4). 32-40.

[7] Feez, S. (2002). Heritage and innovation in second language education. In A. M. Johns (Ed.), Genre in the classroom. Mahwah, NJ: Lawrence Erlbaum

[8] Gokhale, A.A. (2010). Collaborative Learning Enhances Critical Thinking. Journal of Technology Education. Vol. 7. Number 1.

[9] Harmer, Jeremy. (2004). How to Teach Writing. Essex: Longman.

[10]Harmer, Jeremy. (2007). The Practice of English Language Teaching. Cambridge, UK: Longman.

[11]Hoover, K. (2008). Writing: An essential component of literacy. Research Alignment for MM-H California treasures, June: 1-2.

[12]Hudelson, S. (1989). Write on: Children writing in ESL. Englewood Cliffs, NJ: Center for Applied Linguistics and Prentice Hall

[13]Iter, Nuha. (2017). Using Performance Task-GRASPS to Assess Student Performance in Higher Education Courses. American Journal of Educational Research. 2017, 5(5), 552-558. DOI: 10.12691/education-5-5-12.

[14]Jarvis, D. (2000). The process writing method. TESL Journal, vol. 8, no. 7, July.

[15]Kemmis, S.,.\& McTaggart, R. (2007). Participatory Action Research. Denzin \& Lincoln Strategies.

[16]Larson, U. Charles. (2004). Persuasion. Wadsworth/Thomson Learning.

[17] Manning, M. (1999). Writing: Choosing a Topic. Teaching Pre K-8, 35 (1). 130-132.

[18]Meteetham, P. (2001). Case Study of Cooperative Learning by Using Jigsaw Technique with the Second Major Salants at Naresuan University.

[19]Mollestam, E., \& Hu, Lixia, (2016). Corrective Feedback on L2. Students' Writing. Malmo Hongskola. P. 22.

[20]Thomsan, H. (2003). A Case Study on Reflective Journals in a University Level EFL Writing Course in Hungary. Forume, Volume 41, Number 1.

[21]Thornbury, S. (1999). How to Teach Grammar. Harlow: Pearson Education.

[22]Turbill, J. (1983). No Better Way to Teach Writing. Australia: Bridge Printing Pty Ltd.

[23]Krista, Uibu., \& Merili Liiver (2015). Students' Grammar Mistakes and Effective Teaching Strategies. International Journal of Teaching and Education. Vol. III, No. 1 (2015).

[24] Watanabe, Y., \& Swain, M. (2008). Perception of Learner Proficiency: Its impact on the Interaction between an ESL Learner and her Higher and Lower Proficiency Partners, Language Awarenesses, 17. 115-130.

[25]Wiggins, G., \& McTighe, J. (2004). Understanding by Design Professional Development Workbook. Alexandra, VA: Association for Supervision and Curriculum Development.

[26]Wiggins, G., \& McTighe, J. (2005). Understanding by design (2 ${ }^{\text {nd }}$ ed.). Alexandria, VA: Association for Supervision and Curriculum Development, Alexandria, Virginia, USA.

[27]Wiggins, G., \& McTighe, J. (2008). Understanding by design (2 ${ }^{\text {nd }}$ ed.). Alexandria, VA: Association for Supervision and Curriculum Development, Alexandria, Virginia, USA. 